\title{
Upaya Meningkatkan Hasil Belajar Bermain Kasti Melalui Pola Gerak Dasar Lokomotor dan Manipulatif
}

\author{
Nurhikmah \\ Pendidikan Anak Usia Dini, Universitas Muhammadiyah Luwuk \\ Jl. KH. Ahmad Dahlan No. III/79 Luwuk Kab. Banggai Sulawesi TengahTelp./Fax. 0461-21725 \\ E-mail: nurpratama@gmail.com
}

\begin{abstract}
Article Info
Received December 2018

Accepted Februari 2019

Published April 2019
\end{abstract}

Keywords:

Learning Outcomes,

Playing Kasti, Locomotor

and Manipulative Basic

Movement Patterns.

\section{Abstract}

This research was a classroom action research conducted in 4 meetings in the first cycle, and the second cycle was designed through four stages, namely planning, action, observation, and reflection. The data of this study were the basic abilities of playing kasti as psychomotor data and the score of practice questions were as cognitive data. Observation was as effective data. The data source of this research was the IV grade pupils of SDN 1 Luwuk, Banggai Regency, 30 pupils. Data collection on the ability of playing kasti used the running, throwing and catching the ball, hitting the ball, and bouncing the ball techniques assessment sheets as well as multiple choice assessment sheets in the first cycle, and in the second cycle, the data collected were analyzed quantitatively. The quantitative results of the learning outcomes data of playing kasti in the initial conditions were $23.33 \%$ in the complete category with 7 pupils, and after being given the action, the results of learning to play kasti in the first cycle in the complete category was $70.73 \%$, and the number of pupil who completed was 19 pupils, and in the second cycle there was an increase in the percentage of the results of playing kasti in the complete category of $93.33 \%$, and the number of pupil who completed was 28 pupils, and 2 other pupils who did not complete were suffering physical disorders.

\begin{abstract}
Abstrak: Penelitian ini merupakan penelitian tindakan kelas yang dilaksanakan sebanyak 4 kali pertemuan di siklus I dan siklus II dan dirancang melalui empat tahapan yaitu Perencanaan, Pelaksanaan, Observasi, Refleksi. Data penelitian ini adalah kemampuan dasar bermain kasti sebagai data Psikomotor dan nilai soal-soal latihan sebagai nilai kognitif. Pengamatan sebagai data afektif. Sumber data penelitian ini adalah murid kelas IV SDN 1 Luwuk Kabupaten Banggai yang berjumlah 30 orang. Pengumpulan data kemampuan bermain kasti dengan menggunakan lembar penilaian teknik lari, lempar tangkap bola, memukul bola, dan melambungkan bola serta lembar penilaian pilihan ganda pada siklus I dan siklus II data yang terkumpul dianalisis secara kuantitatif. Hasil analisis Kuantitatif data hasil belajar bermain kasti pada kondisi awal 23,33\% dalam kategori tuntas dengan jumlah 7 murid dan setelah diberikan tindakan hasil belajar bermain kasti pada siklus I dalam kategori tuntas adalah 70,73 \% jumlah murid yang tuntas adalah 19 murid dan Pada siklus II terjadi peningkatan prosentase hasil belajar bermain kasti murid dalam kategori tuntas sebesar $93,33 \%$ jumlah murid yang tuntas adalah 28 murid dan 2 murid yang tidak tuntas karena mengalami gangguan pada fisiknya.
\end{abstract}

Kata Kunci : Hasil belajar, bermain kasti, pola gerak dasar lokomotor dan manipulatif 


\section{PENDAHULUAN}

Pendidikan jasmani tidaklah mungkin terlepas dari belajar, untuk lebih spesifiknya dinamakan "pembelajaran" melalui pembelajaranlah anak dapat mengetahui lebih banyak hal, disinilah anak dididik dan dibina untuk menjadi manusia yang berkulitas dari yang tidak bisa menjadi bisa, melalui proses belajar tersebut pendidikan jasmani ingin mewujudkan sumbangannya terhadap perkembangan anak, sebuah perkembangan yang tidak berat sebelah. Perkembangan bersifat menyeluruh, sebab yang dikembangkan bukan saja aspek jasmaniah yang lazim disebut psikomotorik. Namun juga, perkembangan pengetahuan dan penalaran yang dicakup dalam istilah kongnitif. Selain itu dapat dicapai juga perkembangan watak serta sifat-sifat kepribadiannya, yang tercakup dalam istilah perkembangan afektif.

Pembelajaran pendidikan jasmani di SDN 1 Luwuk kabupaten Banggai, terutama kelas IV masih menggunakan pembelajaran konvensional, dari hasil observasi di lapangan saat pembelajaran masih menggunakan peralatan dan kemampauan yang sebenarnya, contohnya pada saat materi perminan kasti guru langsung memberikan permainan kasti tanpa menguasai teknik dalam permainan kasti terlebih dahulu. Dalam kegiatan pembelajaran masih ada beberapa murid yang tidak mengikuti pembelajaran dengan beberapa alasan, diantaranya: tidak bisa bermain dengan baik karena belum mengetahui teknik dasar permainan kasti. Hal ini menyebabkan kemampuan bermain kasti murid Kelas IV SDN 1 Luwukkabupaten Banggai belum optimal, hal ini dibuktikan masih banyak siswa yang nilainya di bawah Kriteria Ketuntasan Minimal (KKM).

Hasil pengamatan peneliti proses pembelajaran permainan kasti di SDN 1 Luwuk Kabupaten Banggai ternyata masih banyak murid yang masih dalam kategori kurang. Dari 30 orang murid Kelas IV, ternyata hanya 7 orang murid $(23,33 \%)$ yang memiliki nilai di atas nilai KKM sedangkan 23 orang murid (76,66\%) memiliki nilai di bawah nilai KKM. Dari data ini dapat disimpulkan bahwa rata-rata nilai kemampuan bermain kasri murid masih rendah.

Jika murid kurang gerak dalam mengikuti pembelajaran pendidikan jasmani maka akan berdampak pada tingkat kemampuan geraknya. Melalui pembelajaran pola gerak dasar lokomotor dan manipulatif diharapkan para 
murid menemukan suasana baru yang menyenangkan dengan suasana yang menyenangkan siswa akan lebih tertarik dan senang dalam mengikuti pembelajaran, sehingga siswa lebih aktif bergerak. Dengan siswa aktif bergerak, maka akan meningkatkan kemampuan bermain kasti.

Untuk mengetahui apakah pola gerak dasar lokomotor dan manipulatif mengoptimalkan kemampuan bermain kasti, maka perlu dilakukan Penelitian Tindakan Kelas dengan judul "Upaya Meningkatkan Hasil Belajar Bermain Kasti Melalui Pola Gerak Dasar Lokomotor dan Manipulatif Melalui pada Murid Kelas IV SDN 1 Luwuk Kabupaten Banggai”.

Tujuan yang ingin dicapai melalui penelitian ini adalah untuk mengetahui peningkatan hasil belajar bermain kasti melalui pola gerak dasar lokomor dan manipulatif pada murid Kelas IV SDN 1 Luwuk Kabupaten Banggai.

\section{Pengertian Belajar}

Haling (2007) mengemukakan pengertian belajar sebagai berikut: (1). Belajar itu merupakan suatu kegiatan yang disadari dan mempunyai tujuan, (2). Proses belajar itu mengakibatkan perubahan tingkah laku, dan perubahan itu disebabkan oleh pengalaman-pengalaman atau latihan-latihan, dan bukan disebabkan oleh pertumbuhan atau kematangan, dan (3). Perubahan tingkah laku dalam belajar sifatnya menetap.

\section{Faktor - faktor yang Mempengaruhi Belajar}

Menurut Slameto (2003) faktor-faktor yang mempengaruhi belajar banyak jenisnya tetapi dapat di golongkan menjadi dua golongan saja, yaitu faktor intern dan ekstern.

\section{Faktor Intern}

- Faktor Jasmaniah terdiri-dari: faktor kesehatan dan cacat tubuh.

- Faktor Psikologis terdiri-dari : faktor intelegensi, perhatian, minat, bakat, motif, kematangan dan kesiapan.

\section{Faktor Eksternal}

- Faktor keluarga yang terdiri-dari: cara orang tua mendidik, relasi antar anggota keluarga, suasana rumah, keadaan ekonomi keluarga, pengertian orang tua. 
- Faktor sekolah terdiri-dari: metode mengajar, kurikulum (relasi guru dengan murid, relasi murid dengan murid, disiplin).

- Faktor Masyarakat terdiri-dari: kegiatan murid, teman bergaul, bentuk kehidupan masyarakat.

\section{Hasil Belajar}

Hasil belajar adalah perubahan perilaku murid akibat belajar. Perubahan perilaku disebabkan karena dia mencapai penguasaan atas sejumlah bahan yang diberikan dalam proses belajar mengajar. Pencapaian itu didasarkan atas tujuan pengajaran yang ditetapkan. Hasil itu dapat berupa perubahan dalam aspek kognitif, afektif, maupun psikomotorik (Purwanto, 2013).

\section{Gerak Dasar Dalam Pendidikan Jasmani}

\section{Gerak lokomotor}

Harianta, dkk (2006) Gerak lokomor adalah gerak berpindah tempat. Contonya jalan, lari, dan lompat. Sedangkan menurut Mulyaningsih, dkk (2010) : gerak lomotor adalah gerak berpindah tempat untuk seluruh tubuh. Contohnya berjalan, berlari, melompat, melangkah, skipping dan sliding. Unsur gerak lokomor dapat dikombinasi.

\section{Gerak Nonlokomotor}

Haryanta, dkk (2006) Gerak nonlokomor adalah gerak tanpa berpindah tempat. Contohnya menekuk, meliuk, menarik dan mendorong.

Sedangkan menurut Mulyaningsih, dkk (2010:4) : gerak nonlokomotor adalah gerak dari bagian tubuh yang berbentuk dalam satu pola yang diam di tempat atau tidak menyebabkan perpindahan tempat. Contohnya mengayun, membungkuk, menekuk, bertepuk tangan, melenting, dan meliukkan badan.

\section{Gerak Manipulatif}

Haryanta, dkk (2006) Gerak manipulatif adalah bergerak memainkan alat. Contohnya melempar, menggulirkan, dan menendang bola. Supriatna, dkk (2006) mendefinisikan gerak manipulatif adalah gerak menggunakan atau memainkan alat. Contohnya melempar, menangkap, menendang, menggulir, dan memukul. 


\section{Permainan Kasti}

Permainan kasti merupakan bentuk permainan bola kecil yang sudah banyak disukai dan digemari oleh masyarakat, dimana permainan ini dikenal sejak di sekolah dasar.

Menurut Sukintaka (1992) yang dimaksud dengan permainan kecil, ialah permainan yang tidak mempunyai peraturan yang baku dan tidak ada organisasi induk. Termasuk di dalamnya ialah permainan anak-anak, kasti, rounders, bola pukul, bola tangan dan bola keranjang.

\section{Karakteristik Murid Sekolah Dasar}

Ada beberapa karakteristik anak di usia Sekolah Dasar yang perlu diketahui para guru, agar lebih mengetahui keadaan peserta didik khususnya ditingkat Sekolah Dasar. Anak adalah individu yang berbeda dengan orang dewasa, seperti cara anak belajar. Menurut Pasau (2012) anak belajar memerlukan bantuan dari benda-benda sebagai alatnya. Oleh karena itu, dikatakan cara anak belajar: learning by doing karena anak masih hidup di dalam dunia yang nyata atau konkret.

\section{METODE}

Penelitian ini tergolong penelitian tindakan yang berbasis kelas (Classroom Action Research) yang bersifat deskriptif dan bertujuan untuk meningkatkan kemampauan gerak dasar lokomor dan manipulatif melalui permainan kasti pada murid kelas IV SDN 1 LuwukKabupaten Banggai Penelitian tindakan kelas ini dilaksanakan di SDN 1 Luwuk Kabupaten Banggai Subyek penelitian adalah murid kelas IV SDN 1 Luwuk Kabupaten Banggai, dengan jumlah murid sebanyak 30 orang, terdiri dari 11 laki-laki dan 19 perempuan pada tahun ajaran 2014/2015.

Teknik pengumpulan data adalah Tes, pada umumnya digunakan untuk menilai kemampuan murid yang mencakup pengetahuan dan keterampilan, bakat dan intelegensi seseorang. Tes yang diberikan berupa tes tulis yang berisi seperangkat pertanyaan atau tugas untuk kemudian dijawab oleh murid. 
Teknik Observasi merupakan teknik pengumpulan data/informasi dengan cara mengamati secara langsung kegiatan pembelajaran yang sedang berlangsung.

Teknik Dokumentasi : Kegiatan dokumentasi yang dimaksudkan untuk mendapatkan data jumlah murid kelas IV SDN 1 Luwuk Kabupaten Banggai yang lebih lengkap dalam menunjang keberhasilan pelaksanaan penelitian terhadap aktivitas kemampuan murid dalam bermain kasti.

Teknik analisis data yang digunakan dalam penelitian tindakan kelas ini adalah data kuantitatif. Data kuantitatif berupa hasil belajar, dianalisis dengan menggunakan teknik analisis deskriftif dengan menggunakan ketuntasan belajar dan mean (rata-rata) kelas.

\section{HASIL DAN PEMBAHASAN}

\section{Data awal hasil belajar bermain kasti murid Kelas IV SDN 1 Luwuk Kabupaten Banggai}

Sebelum melakukan penelitian tindakan kelas terlebih dahulu peneliti melakukan survei atau pengambilan data awal untuk mengetahui keadaan yang terjadi didalam kelas sebelum memberikan tindakan yang akan diberikan oleh peneliti. Berikut adalah hasil data awal sebelum melakukan penelitian di kelas.

Tabel 1. Data awal hasil belajar Bermain Kasti murid SDN 1 Luwuk

$$
\text { Kabupaten Banggai }
$$

\begin{tabular}{lcccc}
\hline No. & Nilai & Kategori & Frekuensi & Persentase (\%) \\
\hline 1. & 80 ke atas & Sangat memuaskan & 0 & $0 \%$ \\
\hline 2. & $70-79$ & Memuaskan & 7 & $23,33 \%$ \\
\hline 3. & $60-69$ & Cukup & 14 & $46,66 \%$ \\
\hline 4. & $50-59$ & Kurang & 9 & $30 \%$ \\
\hline 5. & 49 ke bawah & Sangat kurang & 0 & $0 \%$ \\
\hline & & Jumlah & 30 & $100 \%$ \\
\hline
\end{tabular}

Pada tabel diatas menunjukkan persentase ketuntasan hasil belajar murid pada adalah 23,33\% tuntas dengan jumlah murid 6 dan 76,66\% tidak tuntas dengan jumlah murid 23. 


\section{Deskripsi Hasil Belajar Pada Siklus I}

Tahap penelitian tidakan kelas pada siklus I dalam kemampuan dasar bermain kasti melalui pola gerak dasar lokomotor dan manipulatif dalam meningkatkan hasil belajar kelas IV SDN 1 Luwuk Kabupaten Banggai, yang terdiri dari empat tahapan yakni; a) perencanaan, b) pelaksanaan, c) observasi, d) refleksi. Keempat tahap tersebut dapat diuraikan sebagai berikut :

\section{Perencanaan}

Perencanaan pada siklus pertama sebagai langkah awal dalam penelitian tindakan kelas ini, yaitu mempersiapkan segala sesuatunya dalam rangka pelaksanaan tindakan meliputi:

1. Penyusunan rencana pelaksanaan pembelajaran (RPP) murid kelas IV SDN 1

Luwuk Kabupaten Banggai melalui pola gerak dasar lokomotor dan manipulatif.

2. Menyusun fortmat observasi aktivitas guru dan murid.

3. Menyiapkan media pembelajaran dan sumber belajar.

4. Membuat tes penilaian hasil belajar bermain kasti berdasarkan materi yang diajarkan melalui pola gerak dasar lokomotor dan manipulatif.

\section{Pelaksanaan}

Pelaksanaan tahap penelitian tindakan kelas (PTK) pada siklus I berlangsung sebanyak tiga kali pertemuan, dengan perincian yaitu dua kali pertemuan untuk proses pembelajaran dan satu kali pertemuan untuk tes hasil belajar bermain kasti melalui pola gerak dasar lokomotor dan manipulatif. Setiap pertemuan berlangsung 2 jam pelajaran (2x35 menit). Kegiatan yang dilakukan pada tahap pelaksanaan tindakan meliputi kegiatan awal, kegiatan inti dan kegiatan akhir.

\section{Obsevasi}

Berdasarkan hasil observasi pada siklus I, pada aktivitas guru menunjukan bahwa kegiatan awal, guru memberikan persepsi sebagai dasar penilaian awal, dan dilanjutakan dengan pemanasan secara umum.

Hasil observasi terhadap aktivitas belajar murid dalam mengikuti pelajaran penjasorkes dengan materi bermain kasti melalui pola gerak dasar lokomotor dan manipulatif yaitu tampak bahwa pada kegiatan awal masih ada murid yang kurang 
bersungguh-sungguh melakukan pemanasan kemudian saat masuk di pembelajaran inti masih kurang partisipasi dan perhatian murid dalam pembelajaran dimana murid cenderung bermain-main dan rebut, disamping itu juga masih banyaknya murid yang memperhatikan aktivitas diluar yang mengganggu jalannya pembelajaran.

Hal ini terlihat karena masih ada murid yang cenderung meminta dijelaskan ulang materi pembelajaran yang telah dijelaskan oleh guru dan masih ada yang bingung dalam melakukan aktivitas gerak lokomotor dan manipulatif.

Pada kegiatan akhir dimana murid masih kurang dalam mendengarkan penjelasan tentang materi dari guru hal itu terlihat karena murid masih kurang dalam mengangkat tangan ketika guru meminta murid yang bias memperagakan secara singkat materi yang telah dilakukan dalam proses pembelajran. Setelah semua selesai barulah murid terlihat antusias dalam mendengarkan pesan-pesan dan motivasi dari guru serta memberikan penghargaan kepada murid yang berprestasi.

\section{Hasil Belajar Pada Siklus I}

Kegiatan yang telah dilakukan pada siklus pertama adalah penyajian materi bermain kasti melalui pola gerak dasar lokomotor dan manipulatif pada pembelajaran bermain kasti sebanyak 2 kali pertemuan dan untuk kegiatan tes dilakukan pada pertemuan ketiga atau pengambilan nilai aspek Psikomotor, Afektif dan kognitif. Maka hasil belajar bermain kasti murid dapat di lihat pada table 4.4.

Tabel 2. Deskripsi ketuntasan belajar murid kelas IV SDN 1 Luwuk Kabupaten Banggai

\begin{tabular}{cccc}
\hline Kriteria ketuntasan & Kategori & Frekuensi & Presentasi \\
\hline $\mathbf{0}-\mathbf{6 9}$ & Tidak Tuntas & 11 & $36,66 \%$ \\
\hline $\mathbf{7 0}-\mathbf{1 0 0}$ & Tuntas & 19 & $63,33 \%$ \\
\hline & Jumlah & 30 & $100 \%$
\end{tabular}

Sumber : Analisis data hasil belajar siswa 
Pada tabel diatas menunjukkan persentase ketuntasan hasil belajar murid pada siklus pertama adalah 63,33\% tuntas dari jumlah sebanyak 19 dan 36,66\% tidak tuntas dari jumlah sebanyak 11.

\section{Deskripsi Hasil Belajar Pada Siklus II}

Tahap penelitian tidakan kelas pada siklus II dalam kemampuan dasar bermain kasti melalui pola gerak dasar lokomotor dan manipulatif dalam meningkatkan hasil belajar kelas IV SDN 1 LuwukKabupaten Banggai, yang terdiri dari empat tahapan yakni; a) perencanaan, b) pelaksanaan, c) observasi, d) refleksi. Keempat tahap tersebut dapat diuraikan sebagai berikut :

\section{Perencanaan}

Perencanaan pada siklus pertama sebagai langkah awal dalam penelitian tindakan kelas ini, yaitu mempersiapkan segala sesuatunya dalam rangka pelaksanaan tindakan meliputi :

1. Penyusunan rencana pelaksanaan pembelajaran (RPP) murid kelas IV SDN 1 LuwukKabupaten Banggai melalui pola gerak dasar lokomotor dan manipulatif.

2. Menyusun fortmat observasi aktivitas guru dan murid.

3. Menyiapkan media pembelajaran dan sumber belajar.

4. Membuat tes penilaian hasil belajar bermain kasti berdasarkan materi yang diajarkan melalui pola gerak dasar lokomotor dan manipulatif.

\section{Pelaksanaan}

Pelaksanaan tahap penelitian tindakan kelas (PTK) pada siklus II berlangsung sebanyak tiga kali pertemuan, dengan perincian yaitu dua kali pertemuan untuk proses pembelajran dan satu kali pertemuan untuk tes hasil belajar bermain kasti melalui pola gerak dasar lokomotor dan manipulatif. Setiap pertemuan berlangsung 2 jam pelajaran (2x35 menit). Kegiatan yang dilakukan pada tahap pelaksanaan tindakan meliputi kegiatan awal, kegiatan inti dan kegiatan akhir.

1. Kegiatan awal

Pada kegiatan awal yang dilakukan dalam proses pembelajaran bermain kasti pada siklus I, yaitu : 1) Berbaris dilapangan, 2) berdoa sebelum memulai 
pelajaran, 3) Mengecek kehadiran siswa, kesehatan kuku, dan rambut, 4) Menegur siswa yang belum berpakaian lengkap (olahraga), 5) Menginformasikan permainan yang digunakan dalam pembelajaran, 6) Guru melakukan persepsi sebagai penilaian awal, 7) Guru membagi siswa kedalam kelompok secara heterogen sesuai dengan jenis permainan yang digunakan dalam pembelajaran.

2. Kegiatan Inti

Pada kegiatan inti, guru memperkenalkan materi pelajaran (bahan ajar) mengenai permainan kasti. Kemudian guru menginstruksikan kepada murid berkumpul dengan teman kelompoknya. Setelah semua murid berkumpul kemudian guru memberikan contoh kepada murid permainan yang akan dilakukan. Dengan gerak lokomotor dan manipulatif selama 50 menit. Pada saat melakukan aktivitas pola gerak lokomotor dan manipulatif murid-murid sudah tampak lebih aktif dalam melakukan aktivitas dan sudah mulai melakukan gerakan tanpa ada keragu-raguan.

3. Kegiatan akhir

Pada kegiatan akhir, murid dikumpulkan mendengarkan penjelasan dari guru tentang materi yang telah dilakukan/diajarkan. Kemudian guru menyimpulkan materi bersama murid serta mengemukakan materi yang akan diajarkan pada pertemuan berikutnya. Selain itu guru melakukan refleksi kesalahan-kesalahan gerakan dalam proses pembelajaran murid. Selain itu guru memberikan pesanpesan moral kepada murid.

\section{Obsevasi}

Berdasarkan hasil observasi pada siklus II, pada aktivitas guru menunjukan bahwa kegiatan awal, guru memberikan persepsi sebagai dasar penilaian awal, dan dilanjutakan dengan pemanasan secara umum.

Hasil observasi terhadap aktivitas belajar murid dalam mengikuti pelajaran penjasorkes dengan materi bermain kasti melalui pola gerak dasar lokomotor dan manipulatif yaitu tampak bahwa pada kegiatan awal murid sudah aktif dan bersungguh-sungguh melakukan pemanasan kemudian saat masuk di pembelajaran inti murid-murid sudah berani melakukan aktivitas tanpa ragu-ragu dalam proses pembelajaran gerak dasar lokomotor dan manipulatif. 
Hal ini terlihat karena tidak ada lagi murid yang meminta dijelaskan ulang materi pembelajaran yang telah dijelaskan oleh guru dan tidak ada lagi murid yang bingung dalam melakukan aktivitas gerak lokomotor dan manipulatif.

Pada kegiatan akhir dimana murid memperhatikan dan mendengarkan penjelasan tentang materi dari guru hal itu terlihat karena murid bersemangat dalam mengangkat tangan ketika guru meminta murid yang bias memperagakan secara singkat materi yang telah dilakukan dalam proses pembelajran. Setelah semua selesai barulah murid terlihat antusias dalam mendengarkan pesan-pesan dan motivasi dari guru serta memberikan penghargaan kepada murid yang berprestasi.

\section{Hasil Belajar Pada Siklus II}

Kegiatan yang telah dilakukan pada siklus kedua adalah penyajian materi bermain kasti melalui pola gerak dasar lokomotor dan manipulatif sebanyak 2 kali pertemuan dan untuk kegiatan tes dilakukan pada pertemuan ketiga atau pengambilan nilai aspek Psikomotor, Afektif dan kognitif. Berdasarkan hasil belajar pada siklus kedua, maka persentase ketuntasan belajar murid dapat dilihat pada tabel dibawah ini :

Tabel 3. Deskripsi ketuntasan belajar murid kelas IV SDN 1 Luwuk Kabupaten Banggai

\begin{tabular}{cccc}
\hline Kriteria ketuntasan & Kategori & Frekuensi & Presentase(\%) \\
\hline $0-69$ & Tidak Tuntas & 2 & $6,66 \%$ \\
\hline $70-100$ & Tuntas & 28 & $93,33 \%$
\end{tabular}

Sumber : Analisis data hasil belajar Siklus II

Pada tabel diatas menunjukkan persentase ketuntasan hasil belajar murid pada siklus kedua adalah 93,33\% tuntas dari jumlah sebanyak 28 dan 2 murid yang tidak tuntas dengan persentase $6,66 \%$ karena mengalami gangguan pada fisiknya. 


\section{Pembahasan}

Pada pembelajaran bermain kasti melalui pola gerak dasar lokomotor dan manipulatif SDN 1 Luwuk Kabupaten Banggai, hal ini dapat dilihat dari hasil perbandingan pada siklus I dan Siklus II yang memuaskan.

Tabel 4. Deskripsi ketuntasan belajar murid pada siklus I dan II

\begin{tabular}{ccccccc}
\hline No & Nilai & Kategori & \multicolumn{2}{c}{ Siklus I } & \multicolumn{2}{c}{ Siklus II } \\
\cline { 3 - 7 } & & & Frekuensi & Persentase & Frekuensi & Persentase \\
\hline 1. & $<70,00$ & Tidak Tuntas & 11 & 36,66 & 2 & 6,66 \\
\hline 2. & $>70,00$ & Tuntas & 19 & 63,33 & 28 & 93,33 \\
\hline \multicolumn{2}{c}{ Jumlah } & 30 & 100 & 30 & 100
\end{tabular}

Sumber : Analisis data hasil belajar murid Siklus I dan Siklus II

Berdasarkan tabel 4 persentase ketuntasan belajar bermain kasti mengalami peningkatan, terlihat bahwa ketuntasan belajar murid pada kondisi awal 23,33\%, pada siklus I 63,33\%, dan pada siklus II adalah 93,33\%.

\section{KESIMPULAN}

Penelitian Tindakan Kelas pada murid kelas IV SDN 1 Luwuk Kabupaten Banggai Tahun Ajaran 2017/2018 dilaksanakan dalam dua siklus. Setiap siklus terdiri atas empat tahapan, yaitu: (1) perencanaan, (2) pelaksanaan tindakan, (3) observasi dan interpretasi, dan (4) analisis dan refleksi. Berdasarkan analisis data yang telah dilakukan dan pembahasan yang telah diungkapkan pada BAB IV, diperoleh simpulan bahwa: Pembelajaran melalui pola gerak dasar lokomotor dan manipulatif, dapat meningkatkan hasil belajar bermain kasti pada murid kelas IV SDN 1 Luwuk Kabupaten Banggai Tahun Ajaran 2017/2018. Dari hasil analisis yang diperoleh peningkatan, hasil observasi pada kondisi awal 23,33\% dalam kategori tuntas dengan jumlah 7 murid dan setelah diberikan tindakan hasil belajar bermain kasti pada siklus I dalam kategori tuntas adalah 70,73 \% jumlah murid yang tuntas adalah 19 murid dan Pada siklus II terjadi peningkatan prosentase hasil belajar bermain kasti murid dalam kategori tuntas sebesar 93,33\% jumlah murid yang tuntas adalah 28 murid dan 2 murid yang tidak tuntas karena mengalami gangguan pada fisiknya. 


\section{Saran}

Berdasarkan hasil penelitian yang telah dilakukan bahwa melalui pola gerak dasar lokomotor dan manipulatif dapat meningkatkan hasil belajar murid pada mata pelajaran penjasorkes khususnya pada materi bermain kasti. Oleh karena itu penulis memberikan saran sebagai berikut:

1. Bagi Guru Penjas

Pada saat proses pembelajaran, guru penjas Sekolah Dasar diharapkan menerapkan metode bermain dan memberikan demo atau memperagakan tugas gerak secara berulang supaya siswa lebih jelas memahami tugas gerak yang diberikan, serta memberikan feedback.

2. Bagi Siswa

Harus fokus pada pembelajaran yang sedang dipelajari.

\section{Bagi Sekolah}

Agar menyediakan atau memperbaharui sarana pembelajaran olahraga, jangan hanya memperbaharui sarana pembelajaran lainnya. Perlunya diperbanyak referensi atau buku-buku pendidikan khususnya metode pembelajaran yang mendukung proses pembelajaran.

\section{DAFTAR PUSTAKA}

Haling, Abdul. (2007). Belajar dan Pembelajaran. Makassar: Badan Penerbit UNM.

Haryanta, Juli, dkk. (2006a). Pendidikan Jasmani, Olahraga, dan Kesehatan (untuk SD dan MI Kelas IV). Jakarta Timur: PT Widya Utama.

Mulyaningsih, Farida, dkk. (2010). Pendidikan Jasmani, Olahraga, dan Kesehatan (untuk Kelas IV SD/MI). Jakarta : Pusat Pembukuan Kementerian Pendidikan Nasional.

Pasau, M. Anwar. (2012). Pertumbuhan dan Perkembangan Fisik Pendidikan Jasmani, Olahraga, dan Kesehatan. Makassar: Penerbit UNM.

Purwanto. (2013). Evaluasi Hasil Belajar. Yogyakarta: Pustaka Pelajar.

Slameto. (2003). Belajar dan Faktor-faktor yang Mempengaruhinya. Jakarta: PT Rineka Cipta. 
Sukintaka. (1992). Teori Bermain Untuk D2 PGSD Penjaskes. Departemen Pendidikan dan Kebudayaan Direktorat Pendidikan Tinggi Proyek Pembinaan Tenaga Kependidikan.

Supriatna, Yayat, dkk. (2006a). Pendidikan Jasmani, Olahraga, dan Kesehatan (untuk SD dan MI Kelas IV). Jakarta Timur: PT Widya Utama. 